\title{
RAZPRAVE
}

\section{PROSTORSKI VZOREC VKLJUČEVANJA SLOVENSKIH KMETIJSKIH GOSPODARSTEV V EKOLOŠKO KMETOVANJE}

\author{
AVTORJA \\ dr. Tanja Travnikar \\ Kmetijski inštitut Slovenije, Hacquetova ulica 17, SI - 1000 Ljubljana, Slovenija \\ tanja.travnikar@kis.si \\ dr. Luka Juvančič \\ Univerza v Ljubljani, Biotehniška fakulteta, Jamnikarjeva ulica 101, SI - 1000 Ljubljana, Slovenija \\ luka.juvancic@bf.uni-lj.si
}

DOI: $10.3986 / G V 90203$

UDK: 911.3:631.147(497.4)

COBISS: 1.01

\section{IZVLEČEK}

\section{Prostorski vzorec vključevanja slovenskih kmetijskih gospodarstev v ekološko kmetovanje}

Študija preverja obstoj učinkov prostorskih prelitij v povezavi z odločanjem kmetijskih gospodarstev $v$ Sloveniji za ekološko pridelavo. V njej preverjamo hipotezo, da na prehod v ekološko pridelavo na nekem območju vpliva razširjenost ekološkega kmetijstva $v$ soseščini. Hipotezo smo preverili z uporabo prostorske ekonometrije, kjer z regresijskimi metodami preverjamo vpliv prenosa informacij iz sosedstva oziroma učinkov prostorskih prelitij. Rezultati prostorskega regresijskega modela, v katerega je bilo vključenih 1976 ekoloških kmetij na 28.088 hektarjev kmetijskih zemljišč potrjujejo, da na odločanje kmetijskih gospodarstev o (pre)usmeritvi v ekološko pridelavo vplivajo tudi odločitve pridelovalcev v soseščini in obratno.

\section{KLJUČNE BESEDE}

učinki prostorskih prelitij, prostorska ekonometrija, ekološko kmetijstvo

\section{ABSTRACT \\ Spatial pattern of the integration of farm holdings in Slovenia into organic farming}

The study examines the existence of spatial spillovers in the decision-making process of the conversion of agricultural holdings in Slovenia to organic farming. We tested the hypothesis that the transition to organic agriculture at certain location is influenced by the patterns of the implementation of organic farming in the neighborhood. The hypothesis was verified by the use of spatial econometrics, which is a regressionbased method that checks for the influence of the transmission of information from the neighborhood, or the existence of spatial spillovers. The results of the spatial regression model, which included 1,976 organic farms on 28,088 hectares of agricultural land, confirm that the decision of agricultural holdings to engage in organic production is influenced by the decisions of the neighboring agricultural holdings, and vice versa.

\section{KEY WORDS}

spatial spillover effects, spatial econometrics, organic agricultural production

Uredništvo je prispevek prejelo 3. maja 2018. 


\section{Uvod}

Za slovensko kmetijstvo kot tudi za kmetijstvo ostalih držav članic Evropske Unije je opazen trend pospešenega preusmerjanja kmetijske proizvodnje iz konvencionalnih oblik kmetovanja v bolj trajnostno naravnane oblike, kamor prištevamo tudi ekološko kmetovanje. Ekološko kmetijstvo lahko opredelimo za okolje in človeka bolj prijazno obliko kmetovanja, ki zasleduje cilje varovanja in ohranjanja naravnih virov, dobrega počutja živali, pridelave zdrave in bolj kakovostne hrane ter trajnostnega razvoja podeželja (Bavec s sodelavci 2001; Podmenik 2012). Na razširjenost ekološkega kmetijstva pozitivno vplivajo tudi trendi povpraševanja po hrani ekološkega izvora, ki beleži stalno rast in je že presegla status nišnega trga (Slabe 2015). Ekološko kmetijstvo je deležno tudi posebnih podpor iz naslova skupne kmetijske politike Evropske unije (EU), kjer se je v aktualnem programskem obdobju programa razvoja podeželja 2014-2020 prvič začelo izvajati shemo ekološke pridelave kot samostojni ukrep in ne več kot del kmetijsko-okoljskih plačil (Moussis 2010; Slabe 2015). Ugodne tržne razmere in spodbudno institucionalno okolje (na primer finančne spodbude, ukrepi zaščite okolja, ozaveščanje, svetovanje) sta prispevala k povečani rasti deleža kmetij in kmetijskih zemljišč, vključenih v ekološko kmetovanje. V Sloveniji se je na primer leta 2015 izvajalo ekološko kmetovanje na 8,8\% skupnih kmetijskih zemljišč v uporabi, kar je skoraj enkrat več kot leta 2005 (4,6\%). Podoben trend je značilen tudi na ravni držav članic EU-28, kjer se je ekološko kmetovanje leta 2015 izvajalo na 6,2 \%, leta 2005 pa na 3,6\% skupnih kmetijskih zemljiščih v uporabi (slika 1).

Poleg rasti povpraševanja in javnofinančnih podpor na rast ekološkega kmetovanja vpliva še široka paleta drugih dejavnikov: strukturne spremembe v kmetijstvu (na primer zlasti starostna in izobrazbena struktura pridelovalcev, življenjski slog pridelovalcev), socio-ekonomski kazalniki (na primer gostota

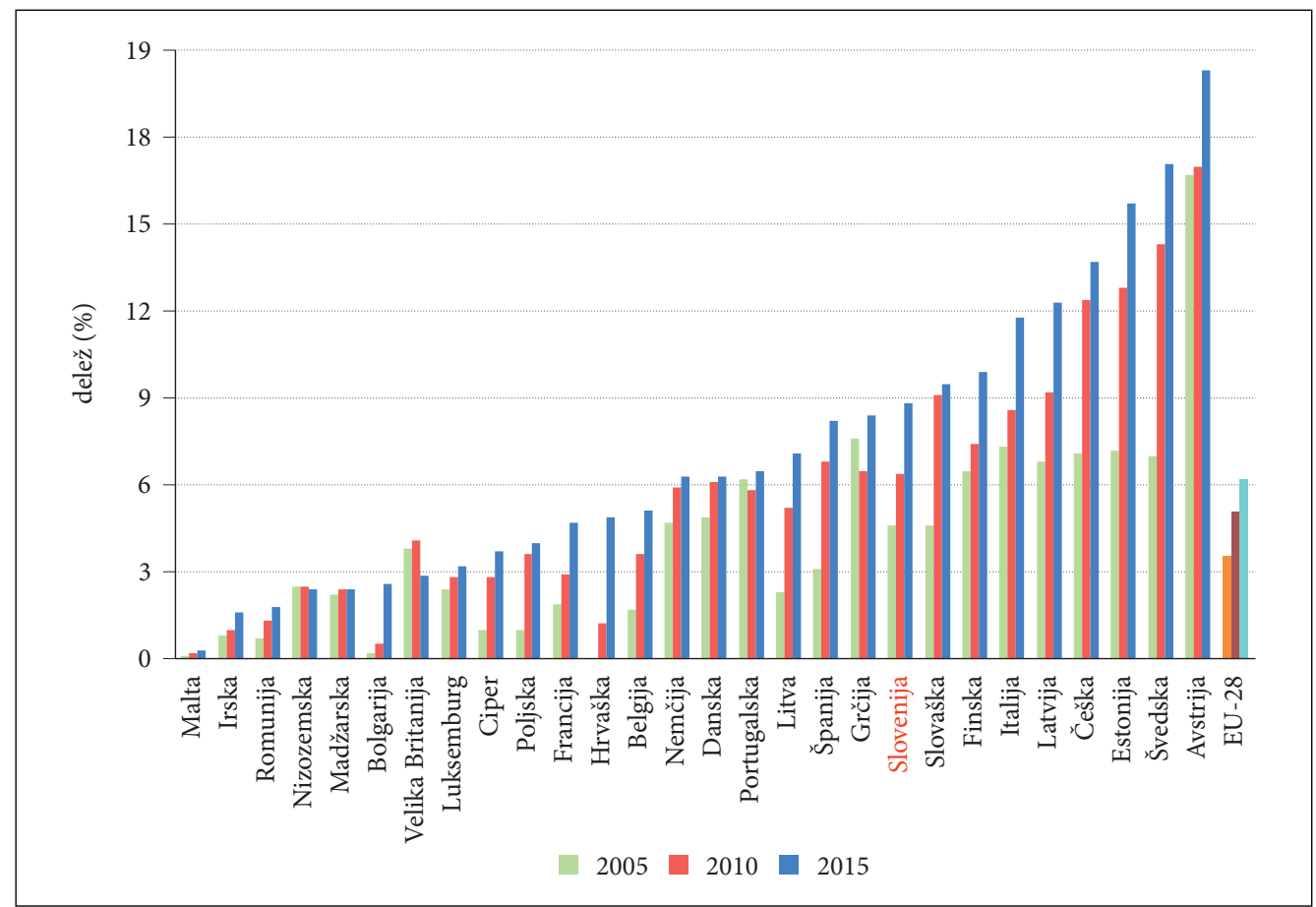

Slika 1: Delež zemljǐ̌č z ekološkim kmetovanjem v EU glede na celotno kmetijsko zemljo v uporabi $v$ letih 2005, 2010 in 2015 (Eurostat 2016). 
naseljenosti, stopnja brezposelnosti), geografske značilnosti (na primer zavarovana območja, območja z omejenimi možnostmi za kmetijsko proizvodnjo, podnebje, oddaljenost od trgov itd.) in spremenjena pričakovanja družbe (poleg preferenc potrošnikov do hrane ekološkega izvora tudi večja splošna okoljska ozaveščenost in skrb za dobrobit živali) (Midmore s sodelavci 2001; Padel 2001; Pietola in Oude Lansink 2001; Koesling, Flaten in Lien 2008). Na temo dejavnikov izvajanja ekološkega kmetijstva so bile izvedene tudi nekatere slovenske raziskave, kot na primer Slabe s sodelavci (2010) (predvsem vpliv trženjskih dejavnikov), Podmenik (2012) (pregled dejavnikov na preusmeritev kmetij v ekološko kmetovanje in stanje v Sloveniji), Slabe, Lampič in Juvančič (2011) (vpliv demografskih dejavnikov na ekološko pridelavo, predvsem analiza starostno-generacijske strukture kmečkih gospodinjstev), Travnikar in Juvančič (2013) (vpliv različnih dejavnikov na preusmeritev v kmetijsko-okoljske ukrepe, s poudarkom na učinkih prostorskih prelitij), Bartolj s sodelavci (2015) (vpliv javnofinančnih podpor na ekološko kmetovanje) ter Slabe (2015) (vpliv različnih notranjih in zunanjih dejavnikov na ekološko kmetovanje za tržno pridelavo).

Dejavniki preusmeritve kmetijskih gospodarstev v ekološko pridelavo so pogostokrat predmet agrarnoekonomskih raziskav, pri čemer pa se le redke študije osredotočajo na vlogo sosedskih učinkov oziroma učinkov prostorskih prelitij. Villano, Fleming in Moss (2016) razlagajo, da so učinki prostorskih prelitij prisotni, kadar imajo dejanja enega pridelovalca vpliv na delovanje njegovih sosednjih pridelovalcev. Prav na slednje se osredotoča pričujoča raziskava, ki se omejuje predvsem na analizo učinkov prostorskih prelitij iz sosedstva. Zanimanje za to izhaja iz nekaterih študij, kjer avtorji ugotavljajo, da imajo učinki prenosa informacij iz sosedstva pomemben vpliv na odločitve pridelovalcev glede preusmeritve v ekološko kmetovanje. To pomeni, da učinki prostorskih prelitij, ki so predvsem posledica sodelovanja in izmenjevanja izkušenj med pridelovalci, prispevajo k večjemu izvajanju ekološkega kmetijstva (Frederiksen in Langer 2004; Bichler s sodelavci 2005; Lewis, Barham in Robinson 2011; Schmidtner s sodelavci 2012; Bjørkhaug in Blekesaune 2013; Wollni in Andersson 2014; Boncinelli s sodelavci 2015; Läppe in Kelley 2015).

Študije, ki so obravnavale učinke prostorskih prelitij, so izhajale iz teze, da kmetije, ki so si geografsko blizu, pogosto razvijejo podobne vzorce obnašanja (Case 1992; Manski 1993; Egri 1999). Pridelovalci imajo možnost povzemanja in osvajanja novih znanj in tehnologij od vrstnikov v sosedstvu, pri čemer velja, da je prenos vzorcev obnašanja večji pri tistih pridelovalcih, ki se geografsko nahajajo blizu (Smit s sodelavci 2015). Potemtakem je povzemanje novih znanj in tehnologij hitrejše v sosedstvu in manjše

\section{Preglednica 1: S prostorsko regresijo potrjeni učinki prostorskih prelitij iz sosedstva pri preusmeritvi $v$ ekološko kmetovanje $\left({ }^{*}\right.$ NUTS, Nomenklatura statističnih teritorialnih enot držav članic EU; Uredba ... 2003).}

\begin{tabular}{|c|c|c|}
\hline preučevana spremenljivka $(y)$ & vir & prostorska aplikacija \\
\hline vključenost kmetijskih zemljišč v ekološko & Bichler s sodelavci 2005 & Nemčija, NUTS $3^{*}$ \\
\hline v uporabi (\%) & Schmidtner s sodelavci 2012 & Nemčija, NUTS 3 \\
\hline \multirow{2}{*}{$\begin{array}{l}\text { vključenost kmetij v ekološko kmetijstvo } \\
\text { od vseh kmetij (\%) }\end{array}$} & Bjørkhaug in Blekesaune 2013 & Norveška, občine \\
\hline & Boncinelli s sodelavci 2015 & Toskana, LAU 2 (NUTS 5) \\
\hline $\begin{array}{l}\text { število kmetij, ki so se vobdobju desetih let } \\
\text { preusmerile v ekološko kmetijstvo }\end{array}$ & Lewis, Barham in Robinson 2011 & Wisconsin, okrožja \\
\hline \multirow{2}{*}{$\begin{array}{l}\text { pripravljenost kmetij za preusmeritev v ekološko } \\
\text { kmetijstvo (da/ne; diskretna spremenljivka) }\end{array}$} & Wollni in Andersson 2014 & La Paz, kmetije \\
\hline & Läppe in Kelley 2015 & Irska, kmetije \\
\hline
\end{tabular}


tam, kjer je razdalja med kmetijami večja, saj se z oddaljenostjo zmanjšuje njihova povezava. Na podlagi te teze je oblikovana tudi hipoteza te raziskave, ki pravi, da odločitve pridelovalcev na nekem območju glede preusmeritve $\mathrm{v}$ ekološko kmetovanje vzajemno vplivajo na odločitve pridelovalcev $\mathrm{v}$ soseščini.

Avtorji v preglednici 1 naštetih študij, so se izzivov identifikacije učinkov prostorskih prelitij iz sosedstva lotevali z uporabo metode prostorske regresije, ki omogoča vpogled v prostorsko razporejanje podatkov, njihovo povezanost in s tem zaznavo vzorcev obnašanja. Metoda temelji na integraciji prostorskih podatkov in ekonometričnih modelov, s čimer zazna morebitne vzorce skupnega vedenja, ki so lahko posledica prostorskih povezovanj. Modeli v študijah so bili uporabljeni na različnih administrativnih prostorskih ravneh. Največkrat je bil predmet obravnave celotna država, pri čemer se je analitična obravnava osredotočala na manjše prostorske ravni. Izbira administrativnih prostorskih enot (na primer občine, statistične regije itd.) je najbolj smiselna zaradi kakovostnejšega zajema različnih statističnih podatkov, ki so pomembni $z$ vidika dodatnih pojasnjevalnih informacij. Poleg tega je smotrno, da regresijske metode obravnavajo obsežnejše podatkovne zbirke.

Namen identifikacije prostorskih vzorcev v sodelovanju kmetij (Lewis, Barham in Robinson 2011; Bjørkhaug in Blekesaune 2013; Wollni in Andersson 2014; Boncinelli s sodelavci 2015; Läppe in Kelley 2015) oziroma vključevanja kmetijskih zemljišč v ekološko pridelavo (Bichler s sodelavci 2005; Schmidtner s sodelavci 2012), je bil preveriti dejavnike, ki vplivajo na odločitve pridelovalcev glede preusmeritve v ekološko kmetovanje ter bolje spoznati dejavnike prostorskih in distribucijskih atributov izvajanja ekološkega kmetijstva. Rezultati navedenih študij so potrdili močan vpliv prostorskih prelitij iz sosedstva, kar pomeni, da je razširjenost ekološkega kmetijstva na nekem območju pod vplivom razširjenosti ekološkega kmetijstva na sosednjih območjih in obratno. Raziskovalci del tega prelitja pripisujejo podobnim naravnogeografskih danostim, del pa tudi temu, da kmetije med seboj sodelujejo na trgu, ali pa zgolj izmenjujejo svoje izkušnje in pričakovanja, s čimer se učinki glede ekonomskih in okoljskih koristi, ki so povezane z ekološkim kmetijstvom, prenašajo po prostoru oziroma med pridelovalci (Lewis, Barham in Robinson 2011).

Poleg informacij potrebnih za identifikacijo učinkov prostorskih prelitij (z matrikami prostorskih povezovanj), so bili v ekonometrične modele omenjenih raziskav vključeni še številni drugi relevantni dejavniki, pri čemer ni opaziti enotne tipologije dejavnikov, kar je lahko povezano tudi z razlikami v dostopnosti podatkov. Študije kažejo, da je območje, kjer se kmetija nahaja, pomemben dejavnik pri odločitvi za preusmeritev v ekološko kmetijstvo. Za preusmeritev se pogosteje odločajo tisti pridelovalci, ki imajo v bližini več pridelovalcev, ki se ukvarjajo $\mathrm{z}$ ekološkim kmetijstvom (Lewis, Barham in Robinson 2011; Schmidtner s sodelavci 2012; Bjørkhaug in Blekesaune 2013). Lewis, Barham in Robinson (2011) razlagajo, da se ti pridelovalci prej preusmerijo, saj hitreje zaznajo obetavnejše priložnosti in koristi v prihodnje. Podobno razlagajo tudi druge študije, ki pravijo, da prepoznavanje pozitivnih učinkov ekološke pridelave, razpoložljiva tehnična in pravna znanja v neki regiji pozitivno vplivajo na povečevanje izvajanja ekološkega kmetijstva v sosednjih regijah (Padel 2001; Schmidtner s sodelavci 2012; Bjørkhaug in Blekesaune 2013). Nadalje pozitivno vpliva visok delež zavarovanih območij (na primer območja Natura 2000 in vodovarstvena območja), območja z omejenimi možnostmi za kmetijsko dejavnost ter slabša kakovost tal (Bichler s sodelavci 2005; Schmidtner s sodelavci 2012; Slabe 2015). Razlago lahko najdemo v tem, da so v primerih zavarovanih območij in slabših pogojev za kmetovanje manjše možnosti za intenziviranje kmetijske pridelave, s čimer je prehod v ekološko kmetijstvo bolj pričakovan. Pozitivno vpliva tudi bližina trga z ekološkimi proizvodi (ekološke trgovine in ekološki predelovalci) in bližina urbanih središč, saj imajo pridelovalci v teh primerih večje možnosti za prodajo ekološko pridelanih pridelkov (Koesling, Flaten in Lien 2008; Lampič s sodelavci 2010; Lewis, Barham in Robinson 2011; Schmidtner s sodelavci 2012; Bjørkhaug in Blekesaune 2013). V raziskavah Bichlerja s sodelavci (2005), Koeslinga, Flatena in Liena (2008) ter Boncinellija s sodelavci (2015) ugotavljajo, da na odločitev pridelovalcev glede preusmeritve pozitivno vplivajo tudi javnofinančni transferji za spodbujanje ekološkega načina kmetovanja (višje podpore povečujejo izvajanje ekološkega kmetovanja). Različni socio-ekonomski kazalniki so običajno v modelih le mejno statistično značilni 
ali neznačilni (na primer družinski prihodki in gostota prebivalstva), kar pomeni, da imajo zanemarljiv vpliv na odločitve pridelovalcev glede preusmeritve v ekološko kmetovanje. Izjema je gostota prebivalstva $v$ raziskavi Bjørkhaug in Blekesaune (2013), ki pozitivno vpliva na preusmeritev, kar je najverjetneje posledica tega, da večja gostota prebivalstva nakazuje na večje možnosti prodaje ekoloških pridelkov (predvsem bližina urbanih središč). Wollni in Andersson (2014) ter Läppe in Kelley (2015) ugotavljajo, da imajo družbene norme najmočnejši vpliv na nastajanje podobnih vzorcev obnašanja, in sicer, da posamezni pridelovalec teži $\mathrm{k}$ temu, da se obnaša $\mathrm{v}$ skladu s pričakovanji njegove socialne skupine (pridelovalci in potrošniki v njegovi bližini). V kolikor se pričakovanja družbe glede odnosa do okolja, zdravja, hrane in podobnega spremenijo, potem se v skladu s temi pričakovanji začnejo spreminjati tudi ravnanja in odločitve pridelovalcev. Od strukturnih podatkov kmetijstva se pogosto izkaže, da kazalniki, ki nakazujejo večjo intenzivnost pridelave, vplivajo negativno (na primer večja intenzivnost živinoreje, tržna usmerjenost in najeta delovna sila) ter obratno kazalniki, ki nakazujejo bolj ekstenzivno pridelavo (Schmidtner s sodelavci 2012; Bjørkhaug in Blekesaune 2013; Wollni in Andersson 2014; Läppe in Kelley 2015; Slabe 2015). V prvem primeru bi kmetije ob preusmeritvi v ekološko kmetovanje zaradi zahtev po zmanjšanju intenzivnosti pridelave poslabšale svoj ekonomski rezultat, $\mathrm{v}$ drugem primeru pa kmetijam ob preusmeritvi obstoječih kmetijskih praks ne bi bilo treba bistveno spreminjati, saj se ekstenzivno kmetovanje v veliki meri že ujema $\mathrm{z}$ ekološkimi zahtevami. Podobno ugotavljajo tudi Koesling, Flaten in Lien (2008), ki pravijo, da predvsem zaradi ekonomskih koristi velik delež pridelovalcev razmišlja o preusmeritvi v ekološko kmetijstvo, vendar bi se v primeru ekonomskih rezultatov, ki bi bili slabši od pričakovanih, odločili za opustitev ekološke pridelave. Fairweather (1999), Koesling, Flaten in Lien (2008) ter Läppe in Kelley (2015) razlagajo, da se za dolgoročnejše ohranjanje ekoloških praks pogosteje odločajo tisti pridelovalci, ki zastopajo okoljske in zdravstvene koristi ter manj ekonomske koristi, kar je povezano predvsem s posameznikovim življenjskim slogom ter identiteto. Slednje pa je v tesni povezavi z družbeno skupnostjo, kjer na posameznikovo identiteto vplivajo obstoječe družbene norme in interesi.

Zgoraj navedeni viri torej potrjujejo učinek prostorskega prelitja pri vključevanju kmetijskih gospodarstev in zemljišč v ekološko pridelavo, sam kontekst prostorske povezanosti in drugi dejavniki, ki vplivajo na razširjenost ekološke pridelave, pa se od primera do primera razlikujejo.

Na teh ugotovitvah gradi tudi pričujoča raziskava. Poleg preverjanja, ali tudi v primeru ekološkega kmetijstva v Sloveniji lahko govorimo o učinkih prostorskih prelitij, nas zanima tudi kontekst teh učinkov ter preostali pomembni dejavniki odločanja kmetijskih gospodarstev za usmeritev v ekološko pridelavo. Tega izziva se podobno kot sorodne študije lotevamo $\mathrm{z}$ uporabo prostorske ekonometrije. Metoda je opisana v naslednjem poglavju, kjer predstavljamo osnovna teoretska izhodišča, pripravo podatkov in metodološke korake empirične izvedbe. Sledi predstavitev rezultatov uporabljenega ekonometričnega modela, ki smo jih v poglavju Diskusija soočili z zastavljeno hipotezo ter z rezultati sorodnih študij. Ključne ugotovitve smo strnili v poglavju Sklep.

\section{Metodologija}

\subsection{Splošni opis prostorske ekonometrije}

V raziskavi smo za identifikacijo učinkov prenosa informacij iz sosedstva glede odločitev kmetij o preusmeritvi v ekološko kmetovanje uporabili metodo prostorske ekonometrije. Gre za nadgradnjo standardnega ekonometričnega pristopa, $v$ katerem upoštevamo še prostorske interakcije in s tem identificiramo obstoj prostorskih vzorcev (Anselin 1988; LeSage in Pace 2010). Na ta način lahko prostorski modeli zaznajo učinke prenosa informacij iz sosedstva, ki jih v prostorski ekonometriji imenujemo učinki prostorskih prelitij (ang. spatial spillover effects). Navadne regresijske modele nadgradimo s prostorsko utežno matriko, ki vsebuje prostorske interakcije sosedstva. Prostorsko strukturo sosedstva z vrsticami (i) 
in stolpci $(j)$ ter z elementi utežne matrike $\left(w_{i j}\right)$ določimo za vsako posamezno opazovanje. Poznamo več vrst matrik, ki določajo sosedstvo po različnih kriterijih (za več informacij priporočamo branje Anselin in Smirnov 1996; Anselin 2002 ter Getis 2010), pri čemer so najpogosteje uporabljene binarne oblike. $\mathrm{V}$ tem primeru tako imenovanim sosedom priredimo vrednost 1 , nesosedom in opazovanjem samim s seboj pa vrednost 0 .

S prostorskim modelom $y=\rho W_{1} y+X \beta+u ; u=\lambda W_{2} u+\varepsilon, \mathcal{E} \sim N\left(0, \sigma^{2} I_{n}\right)$ analiziramo preučevano spremenljivko $y$, ki jo pojasnjujemo $\mathrm{z}$ naborom neodvisnim spremenljivk $X, \beta$ vektorjem pripadajočih parametrov modela ter prostorsko matriko $W$. Ta se navezuje na odvisno spremenljivko $W y$ in na napako modela $W u$ ter predstavlja prostorsko strukturo sosedstva. Vektor napak $u$ predstavlja povprečje 0 , konstantnost variance ter normalno porazdelitev; $\mathcal{E} \sim N\left(0, \sigma^{2} I_{n}\right)$. Rho $(\rho)$ je koeficient prostorskega odloga in lambda $(\lambda)$ koeficient prostorske napake, oba koeficienta pa predstavljata stopnjo prostorske povezanosti spremenljivk. Ob različnih scenarijih prostorskih prelitij lahko iz zgornje specifikacije izluščimo tri modele:

1) Linearni model $(\rho=0 ; \lambda=0)$ : Če model ne vsebuje prostorskih prelitij, niti prostorske avtokorelacije $(\rho)$ niti prostorske heterogenosti $(\lambda)$, potem zgornja specifikacija prostorskega modela predstavlja navaden linearni model $y=X \beta+u$. V tem primeru učinki prostorskih prelitij niso potrjeni, $s$ čimer prenosa informacij iz sosedstva ne morejo potrditi.

2) Model prostorskega odloga $(\lambda=0)$ : Pri preučevanju prostorskega učinka avtokorelacije, kjer je odvisna spremenljivka ene lokacije delno predvidena iz sosednjih lokacij in kadar je koeficient prostorske napake $\lambda$ enak 0 , uporabimo model prostorskega odloga (ang. spatial lag model); $y=\rho W y+X \beta+u$, $u \sim N\left(0, \sigma^{2} I_{n}\right)$. V tem primeru obstaja neposredno prostorsko prelitje prenosa informacij iz sosedstva, torej iz preučevane spremenljivke $y$ na neki lokaciji na preučevane spremenljivke $y$ na sosednih lokacijah.

3) Model prostorske napake $(\rho=0)$ : V primeru, ko model zazna prostorske učinke, vendar ne more potrditi, da ti prihajajo iz odvisne spremenljivke $y$, potem uporabimo model prostorske napake (ang. spatial error model); $y=X \beta+[I-\lambda W]^{-1} \varepsilon, \varepsilon \sim N\left(0, \sigma^{2} I_{n}\right)$. Model uporabimo, kadar je koeficient prostorskega odloga $\rho$ enak 0 in so prostorski učinki ujeti v napaki modela.

Eden od metodoloških korakov prostorske ekonometrije je prostorsko raziskovanje podatkov po pristopu ESDA (ang. Exploratory Spatial Data Analysis), kjer preučujemo prisotnost prostorskih vzorcev (Anselin 1995; 2005). Preverjamo, ali prihaja do sistematičnega razporejanja visokih ali nizkih vrednosti analiziranih spremenljivk po prostoru. Pri tem najpogosteje uporabljamo karto značilnosti LISA (ang. Local Indicators of Spatial Association) in Moranovo I statistiko. LISA razkriva, ali imamo statistično značilne prostorske vzorce opazovane spremenljivke. Razlikujemo lahko med skupinami regij z visokimi (tako imenovane vroče točke) oziroma $\mathrm{z}$ nizkimi vrednostmi (tako imenovane mrzle točke). Poleg njiju opazujemo še dva tipa prostorskih vzorcev, bodisi regije $\mathrm{z}$ visokimi vrednostmi opazovane spremenljivke ter obdane $\mathrm{z}$ regijami nizkih vrednosti in obratno, regije $\mathrm{z}$ nizkimi vrednostmi obdane $\mathrm{z}$ regijami visokih vrednosti. Moranova I statistika vsebuje test prostorske avtokorelacije, s katerim odkrivamo stopnjo prostorske povezanosti preučevanih spremenljivk (Moran 1948). Koeficient Moran I zavzema vrednosti od -1 do +1 , kjer vrednosti okoli 0 predstavljajo naključno razporejene vrednosti po prostoru (naključno razporejanje visokih in nizkih vrednosti) in o nastajanju prostorskih vzorcev ne moremo govoriti. Vrednosti proti +1 kažejo na visoko pozitivno prostorsko avtokorelacijo (visokih ali nizkih vrednosti), blizu -1 pa na negativno prostorsko avtokorelacijo.

V zadnjem koraku uporabimo diagnostične Lagrangeove LM teste (za več informacij priporočamo branje Anselin s sodelavci 1996 ter Florax, Voortman in Brouwer 2002), ki nam povedo, kateri model najbolje pojasnjuje odvisno spremenljivko, s čimer pretehtamo smotrnost uporabe posameznih modelov in izberemo najprimernejši model (standardni regresijski model, model prostorskega odloga ali model prostorske napake). 


\subsection{Priprava podatkov}

Za prostorsko raven obravnave smo izbrali občine (LAU 2), čemur je sledila tudi celotna priprava in organizacija podatkov. V analizo je bilo vključenih 1976 kmetij s skupno površino kmetijskih zemljišč 28.088 hektarjev. Zajete so bile vse kmetije, ki so leta 2009 sodelovale v shemi ekološkega kmetovanja, ki se je izvajala znotraj kmetijsko-okoljskih ukrepov iz programskega obdobja politike razvoja podeželja 2007-2013. Ta vzorec predstavlja okoli $94 \%$ vseh kmetij, ki so bile v letu 2009 vključene v ekološko kontrolo. Pridobili smo individualne podatke na ravni posamezne kmetije, ki smo jih v naslednjem koraku agregirali na raven občin. Po vzoru študij Bichlerja s sodelavci (2005), Schmidtnerja s sodelavci (2012), Bjørkhauga in Blekesaunea (2013) in Boncinellija s sodelavci (2015) smo oblikovali odločitveni model:

$y$ (kmetijska zemljišča v ekološkem kmetovanju od vseh kmetijskih zemljišč v uporabi, \%)

$=\beta_{0}+\beta_{1} X_{1}$ (strukturni podatki kmetijstva)

$+\beta_{2} X_{2}$ (socio-ekonomski kazalniki)

$+\beta_{3} X_{3}$ (geografske značilnosti)

$+\beta_{4} X_{4}$ (podatki o izvajanju ekološkega kmetovanja)

$+\varepsilon$,

kjer kot preučevana spremenljivka v regresijskem modelu nastopa delež kmetijskih zemljišč v ekološkem kmetovanju od vseh kmetijskih zemljišč v uporabi. V skladu s prakso ekonometričnih preučevanj strukturnih sprememb v kmetijstvu smo pojasnjevalne spremenljivke izbirali med različnimi strukturnimi kazalniki kmetijstva, kot so strukturne značilnosti kmetij (na primer fizična velikost, ekonomska velikost, mehanizacija), značilnosti kmetovalcev (starost, spol in izobrazba gospodarjev) in usmeritve kmetijske pridelave (na primer različne rastlinske in živinorejske proizvodne usmeritve, konvencionalne oziroma druge bolj trajnostne oblike kmetovanja). Vključili smo še socio-ekonomske kazalnike (na primer gostota poselitve, stopnja brezposelnosti, izobrazba prebivalstva), geografske značilnosti (območja Nature 2000, vodovarstvena območja in območja z omejenimi možnostmi za kmetijsko dejavnost) ter podatke o izvajanju ekološkega kmetovanja (na primer površine, plačilne pravice, višina finančnih podpor). Pri tem so bili podatki o ekološkem kmetovanju in nekateri strukturni podatki kmetijstva pridobljeni na ravni posamezne kmetije (primarni podatki iz zbirnih vlog za podpore ekološki pridelavi za leto 2009, katerih zbiranje je v domeni Agencije Republike Slovenije za kmetijske trge in razvoj podeželja). Za potrebe prostorske analize so bili individualni podatki agregirani na raven občin. Ostale potencialne pojasnjevalne spremenljivke smo pridobili iz sekundarnih statistik (Statistični urad Republike Slovenije in Agencija Republike Slovenije za okolje), kjer so bili podatki že organizirani na ravni občin. Iz osnovnih podatkov smo oblikovali tudi nekatere sestavljene spremenljivke, na primer oblikovanje različnih velikostnih razredov kmetijskih gospodarstev. Za izračun preučevane spremenljivke na ravni občin smo uporabili primarno (kmetijska zemljišča v ekološkem kmetovanju) in sekundarno statistiko (kmetijska zemljišča $\mathrm{v}$ uporabi).

Po oblikovanem regresijskem modelu smo podatke prostorsko povezali, kar smo naredili s prostorsko utežno matriko (slika 2). S tem smo vključili prostorske interakcije sosedstva, kjer nas je zanimalo, ali na preučevano spremenljivko vplivajo tudi učinki prostorskih prelitij. Za to študijo je bila izbrana binarna matrika, ki temelji na kriteriju skupne meje: če si občini delita skupno mejo, sta sosedi $\left(w_{i j}=1\right)$, v nasprotnem primeru ne $\left(w_{i j}=0\right)$. Matrika vsebuje $210 \times 210$ interakcij (leta 2009 je bilo 210 občin, od leta 2011 pa 212), kar pomeni skupaj 44.100 uteži. Število sosedov posameznih občin je različno, na primer občini Hodoš in Središče ob Dravi imata le enega soseda, Ljubljana pa največ, in sicer 14 sosedov. Matrika je bila pred vstopom v model vrstično standardizirana.

Priprava podatkov, izračuni osnovnih statistik in korelacijskih matrik, razvoj modelov (neprostorskih in prostorskih), testi preverjanja tehnične kakovosti modelov ter prostorska povezava podatkov $\mathrm{z}$ utežno matriko so potekali v statističnem programu $R$. V programu GeoDa pa smo z metodo preučevanja prisotnosti prostorskih vzorcev v podatkih (predvsem LISA karto prostorskih vzorcev in Moranovo 


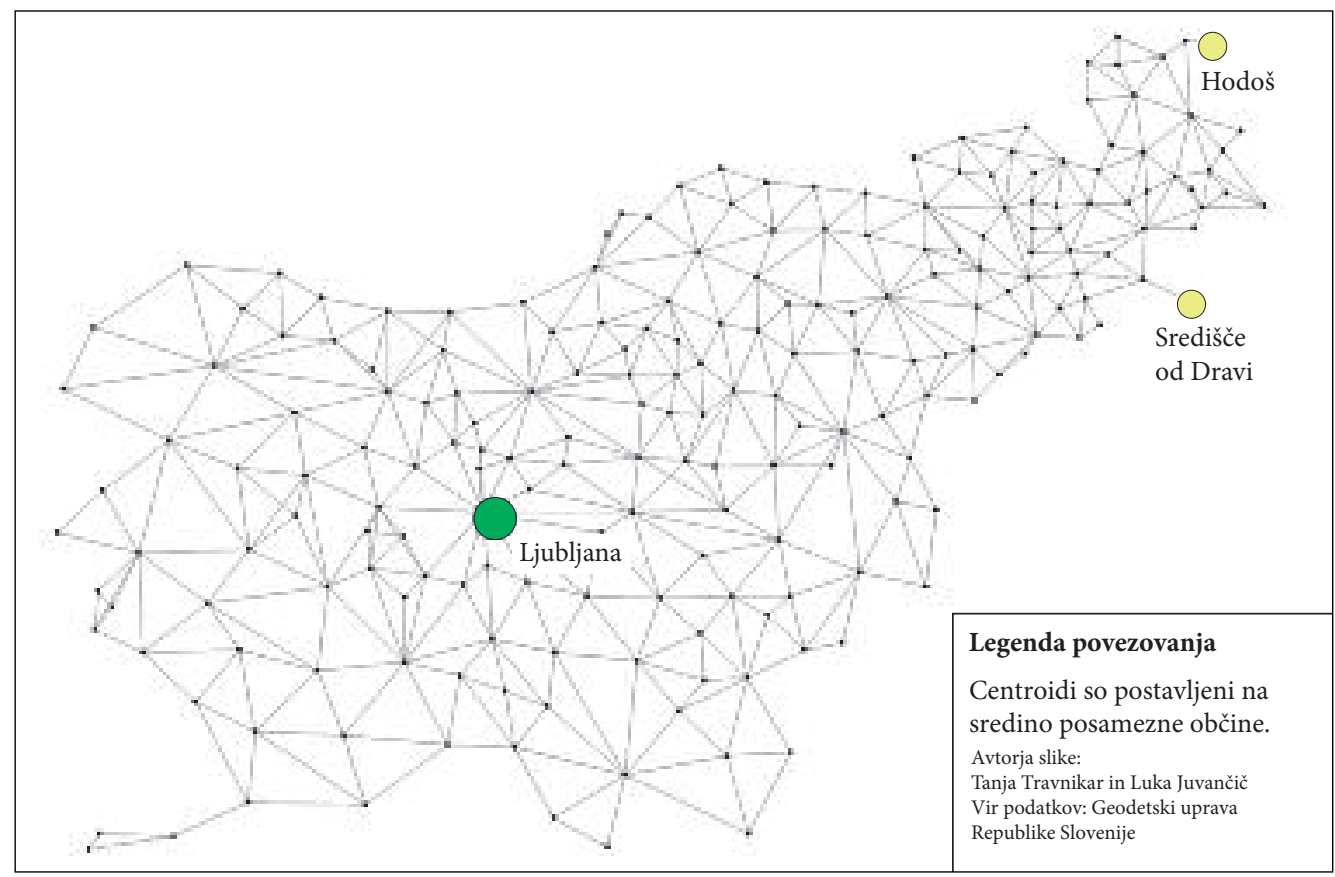

Slika 2: Prostorske interakcije sosedstva slovenskih občin.

I statistiko) preučili relevantne spremenljivke modela $(Y, X)$. Potrdili smo obstoj prostorskega zgoščevanja, kar je podkrepilo odločitev o vključitvi prostorske utežne matrike v regresijski model. V zadnjem koraku smo uporabili še diagnostične Lagrangeove LM teste, s katerimi preverjamo smiselnost uporabe prostorske regresije in izbiro najprimernejšega prostorskega modela (model prostorskega odloga ali model prostorske napake).

\section{Rezultati}

Karta prostorskih vzorcev LISA (slika 3) nakazuje, da na vključenost kmetijskih zemljišč v ekološko kmetovanje v Sloveniji med drugim vplivajo tudi učinki prenosa informacij iz sosedstva. Kot je razvidno iz slike 3, zaznavamo intenzivno prostorsko zgoščevanje odločanja (pa tudi neodločanja) za ekološko pridelavo med posameznimi slovenskimi občinami, kar potrjuje tudi visoka vrednost Moranovega I koeficienta $(0,53)$. Prikaz identificira območja, kjer se po načelu prenosa informacij iz sosedstva pridelovalci v večjem (rdeče obarvane občine) oziroma v manjšem (modro obarvane občine) obsegu odločajo za preusmeritev v ekološko kmetovanje. Večje prostorske skupke, kjer gre za največje pozitivne učinke prostorskih prelitij iz sosedstva smo identificirali predvsem v vzpetem zahodnem delu Slovenije in kraškem južnem delu ter v vzpetem svetu občin Koroške regije. Pri tem del prostorskega zgoščevanja lahko zagotovo pripišemo naravnogeografskim danostim, saj je ekološko kmetijstvo pogosteje zastopano na območjih ekstenzivnega travinja (predvsem kraška in vzpeta območja), manj pogosteje pa v nižinskih območjih, kjer naravne razmere omogočajo intenzivnejše kmetovanje. Slednje potrjujejo tudi modro obarvane občine večinskega dela Podravske in Pomurske regije, kjer so pogoji za kmetijstvo najugodnejši in je kmetijstvo tudi splošno bolj zastopano. Na drugi strani pa del prostorskega zgoščevanja pripisujemo tudi sodelovanju in izmenjevanju izkušenj med pridelovalci. Glede na grafično ponazoritev so 


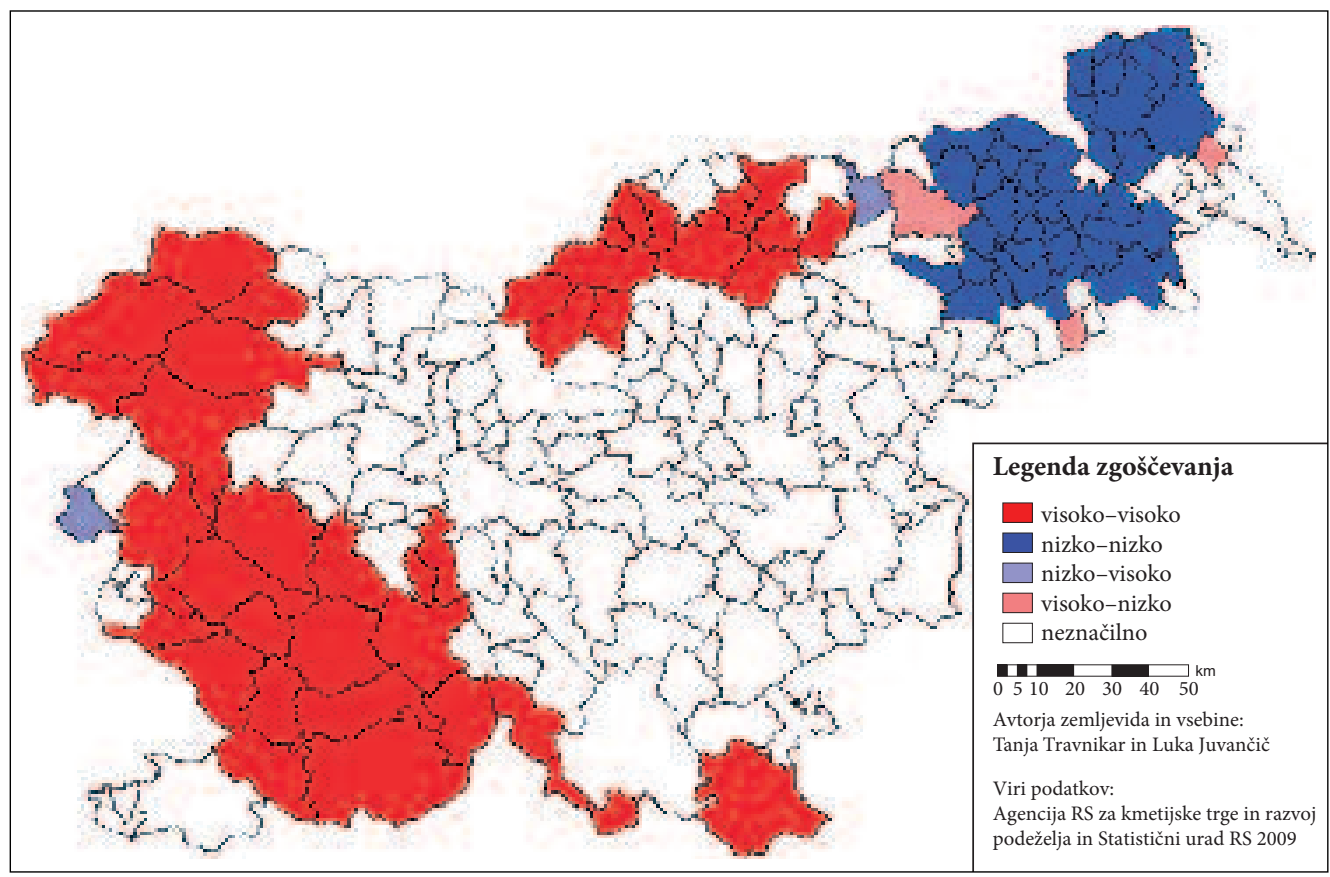

Slika 3: Karta LISA prostorskih vzorcev vključenosti kmetijskih zemljišč v ekološko kmetovanje.

učinki prenosa informacij iz sosedstva najbolj izraziti v vzpetem zahodnem delu Slovenije, kraškem južnem delu ter v vzpetem svetu občin Koroške regije. Najmanj prisotni učinki prenosa informacij iz sosedstva so v primeru modro obarvanih območij večinskega dela Podravske in Pomurske regije, kjer lahko pričakujemo, da bo tudi v prihodnje prenos učinkov informacij iz sosedstva počasnejši. Določeno vlogo ima najverjetneje tudi delovanje kmetijskosvetovalnih služb. V kolikor kmetijskosvetovalna služba prepoznava pozitivne učinke ekološke pridelave, se lahko to odrazi v povečanem sodelovanju kmetij v tej shemi. Enako velja obratno; v kolikor kmetijska svetovalna služba nekega območja ne prepoznava pozitivnih učinkov ekološkega kmetijstva, ga ne bo promovirala, kar bi se lahko odrazilo z manjšo vključenostjo kmetij v ta ukrep. Vendar poudarjamo, da tega pričujoča raziskava empirično ne preučuje in gre zgolj za ugibanja.

Diagnostični LM testi so statistično značilno potrdili, da na vključenost kmetijskih zemljišč v ekološko kmetovanje vplivajo tudi učinki prostorskih prelitij. Potemtakem velja, da če je delež ekološkega kmetovanja v neki občini visok, bo obstajala večja verjetnost, da bo ta delež visok tudi v sosednjih občinah in obratno. Pri občinah, ki niso obarvane gre za naključno razporejanje podatkov po prostoru, kar pomeni, da se prostorski skupki ne tvorijo. Pri teh občinah potemtakem modeli niso zaznali učinkov prenosa informacij iz sosedstva, zato $\mathrm{v}$ teh primerih zastavljene hipoteze ne moremo potrditi. Testi kažejo, da je model prostorskega odloga boljši od navadnega modela, saj lahko z dodatno spremenljivko (vpliv sosedstva) pojasnimo več variabilnosti modela. Smiselnost uporabe prostorske regresije potrjuje tudi nižja vrednost Akaikejevega informacijskega kriterija (AIC), kar nam skupaj s prej naštetim daje zadostne razloge, da navaden regresijski model nadgradimo s spremenljivko prostora.

Koeficient prostorskega odloga $(\rho)$ kaže na sistematično razporejanje izvajanja ekološkega kmetovanja med slovenskimi občinami, in sicer, če bi se delež kmetijskih zemljišč v ekološkem kmetovanju v eni občini povečal za $1 \%$, bi se delež kmetijskih zemljišč v ekološkem kmetovanju sosednjih občin 
v povprečju povečal za $0,28 \%$. S tem prostorski model potrjuje, da odločitve pridelovalcev nekega območja glede preusmeritve v ekološko kmetovanje vplivajo na odločitve pridelovalcev v soseščini in obratno.

Model hkrati razkriva še nekatere druge dejavnike, ki statistično značilno vplivajo na preusmeritev v ekološko kmetovanje (preglednica 2). Večinoma gre za spremenljivke, ki nakazujejo intenzivnost kmetijske pridelave. Dve spremenljivki, ki opisujeta ekonomsko velikost kmetij nakazujeta, da delež ekološkega kmetovanja v občini narašča tam, kjer prevladuje manj intenzivno kmetijstvo in obratno v tistih občinah, kjer imajo kmetije večjo ekonomsko velikost. Če bi se ekonomska velikost kmetijskih zemljišč oziroma kmetij v eni občini povečala za $1 \%$, bi pričakovali zmanjšanje kmetijskih zemljišč v ekološkem kmetovanju za približno enak odstotni delež (za $1 \%$ oziroma za 1,2 \%). V strukturi ekološkega kmetovanja v Sloveniji prevladujejo kmetije, ki se ukvarjajo z ekstenzivno živinorejo, kar se odraža tudi v modelnih rezultatih. Večji kot bi bil delež kmetij v občini, usmerjenih v živinorejo, večja bi bila pokritost občin z ekološkim kmetovanjem. Nadalje, model ne potrjuje, da bi območja posebnega okoljskega pomena (Natura 2000 in območja z omejenimi možnostmi za kmetijsko dejavnost) statistično značilno vplivala na večjo zastopanost ekološkega kmetovanja v občinah. Na podlagi modelnih rezultatov bi lahko sklepali, da so ekonomski kazalniki pomembnejši od naravnogeografskih omejitev. Model na primer kaže, da se s povečevanjem neposrednih plačil na hektar (v modelu jih ponazarjamo s podatkom o plačilnih pravicah) zmanjšuje vključenost kmetijskih zemljišč v ekološko kmetovanje. Povedano drugače, če bi kmetija prejela višja neposredna plačila, bi se interes po ekološki pridelavi zmanjšal. Dodatno to potrjuje spremenljivka, ki opisuje obseg izvajanja kmetijsko-okoljskih ukrepov na njivskih zemljiščih. Večja njivska zemljišča v občini pomenijo tudi večji obseg plačilnih pravic in s tem manjši interes po preusmeritvi v ekološko kmetovanje. Hkrati večji obseg njiv v občini pomeni tudi bolj intenzivno pridelavo in s tem manjše zanimanje za ekološko kmetovanje. Sorodna spremenljivka v modelu (obseg izvajanja kmetijsko-okoljskih ukrepov na travinju) prav tako potrjuje,

Preglednica 2: Rezultati modela dejavnikov preusmeritve v ekološko kmetovanje.

vključenost kmetijkkih zemljišč v ekološko standardni model prostorski model kmetovanje, $\log (y)$

koeficient p-vrednost koeficient p-vrednost

\begin{tabular}{|c|c|c|c|c|}
\hline ekonomska velikost, $\log \left(\mathrm{SO}^{*} \mathrm{v} 1000\right.$ evrov/ha KZU**) & $-0,996$ & 0,000 & $-0,817$ & 0,000 \\
\hline ekonomska velikost, log (SO v evrov/kmetijo) & $-1,220$ & 0,000 & $-0,992$ & 0,000 \\
\hline delež kmetij, usmerjenih v živinorejo, log (\%) & 0,229 & 0,001 & 0,166 & 0,011 \\
\hline delež območij Nature 2000 v občini, $\log (\%)$ & 0,039 & 0,274 & 0,046 & 0,164 \\
\hline območja z omejenimi možnostmi za kmetijsko dejavnost, log (\%) & 0,043 & 0,226 & 0,040 & 0,228 \\
\hline višina prejetih plačilnih pravic na ha KZU, log (evrov/ha) & $-2,775$ & 0,000 & $-2,205$ & 0,000 \\
\hline povprečna velikost izvajanja neto njivskih ukrepov, log (ha) & $-0,266$ & 0,000 & $-0,198$ & 0,002 \\
\hline povprečna velikost izvajanja neto travniških ukrepov, log (ha) & 0,247 & 0,012 & 0,181 & 0,049 \\
\hline konstanta & 15,029 & 0,000 & 11,726 & 0,000 \\
\hline$R^{2}(\%)$ & 58,01 & 61,25 & & \\
\hline Rho $(\rho)$ & & & 0,279 & 0,000 \\
\hline Breusch-Paganov test (BP) & 20,483 & 0,009 & 21,371 & 0,006 \\
\hline Akaikejev informacijski kriterij (AIC) & 535,35 & 523,66 & & \\
\hline
\end{tabular}

* SO, standardni prihodek. Za vsak kmetijski proizvod (pridelek ali živina) obstaja koeficient SO, ki predstavlja povprečno denarno vrednost kmetijske bruto proizvodnje v evrih na hektar oziroma na glavo živine. Na podlagi tega izračunamo ekonomsko velikost kmetij, ki vsebuje vsoto posameznih SO vseh kmetijskih proizvodov na kmetiji.

** KZU, kmetijska zemljišča v uporabi (ha). 
da večja travniška zemljišča označujejo bolj ekstenzivno kmetovanje, kar pozitivno vpliva na preusmeritev v ekološko kmetovanje.

Zgornji rezultati se nanašajo na optimalni regresijski model, ki pa vključuje zgolj del potencialnih dejavnikov, ki lahko vplivajo na preusmeritev pridelovalcev v ekološko kmetovanje. Za dodaten vpogled $\mathrm{v}$ dejavnike preusmeritve in za primerjavo $\mathrm{z}$ rezultati sorodnih študij, $\mathrm{v}$ preglednici 3 naštevamo še nekatere povezave med preučevano spremenljivko (delež zemljišč v ekološki pridelavi) in potencialnimi kandidati za pojasnjevalne spremenljivke $(x)$. Ob tem poudarjamo, da so v preglednici podane zgolj parne korelacijske povezave, ne pa tudi povezave vzajemnega učinka med dejavniki, kar pomeni, da obstoječa statistična značilnost v regresijskih modelih morebiti ne bi veljala več, zato je treba te povezave obravnavati $z$ nekaj pridržka.

Pregled interakcij začenjamo $\mathrm{z}$ dejavniki, kjer povezava ni bila statistično značilna. Med njimi najdemo dejavnike, kot so obseg razpoložljivega dela na kmetiji, velikost kmečke družine in starost njenih članov. Zanimivo, da povezava ni bila potrjena pri večji tržni usmerjenosti kmetij in večji fizični velikosti kmetij (oba dejavnika namreč nakazujeta večjo intenzivnost pridelave). Na drugi strani ugotavljamo

Preglednica 3: Povezave med deležem zemljišč v ekološki pridelavi in izbranimi spremenljivkami.

$\begin{array}{lll}\text { povezava je pozitivna } & \text { povezava je negativna } & \text { povezava ni statistično } \\ \text { in statistično značilna } & \text { in statistično značilna } & \text { značilna }\end{array}$

\section{strukturni podatki kmetijstva}

- srednje velike kmetije

(5-10 ha KZU),

- živinorejska proizvodna usmeritev, • manjše kmetije (0-5 ha KZU),

- travniki in pašniki v občini
- ekonomska velikost,

- rastlinska proizvodna usmeritev,

- njive v občini
- delovna moč na kmetiji,

- velikost družine na kmetiji,

- starost družinskih članov kmetije,

- tržna usmerjenost,

- velike kmetije ( $\geq 10$ ha KZU),

- trajni nasadi v občini

\section{socio-ekonomski kazalniki}

- starost prebivalstva,

- višja stopna izobrazbe prebivalstva
- gostota naseljenosti,

- nižja stopnja izobrazbe prebivalstva,

- več samozaposlenih kmetov,

- večja stopna brezposelnosti

\section{geografske značilnosti}

- območja z omejenimi možnostmi za kmetijstvo,

- območja Nature 2000,

- vodovarstvena območja

\section{podatki povezani z izvajanjem ekološkega kmetovanja}

- višina prejetih javnofinančnih transferjev (ekološko kmetovanje),

- obseg izvajanja kmetijskookoljskih ukrepov na travinju
- višina prejetih javnofinančnih transferjev (plačilne pravice),

- obseg izvajanja kmetijskookoljskih ukrepov na njivah
- povprečna mesečna neto plača 
statistično značilno pozitivno povezavo pri srednje velikih kmetijah in negativno pri majhnih kmetijah. Izhajajoč iz tega lahko sklepamo, da bo verjetnost za preusmeritev v ekološko kmetovanje največja pri srednje velikih kmetijah (od 5 do 10 hektarjev). Pričakovano, finančne podpore ekološki pridelavi pozitivno vplivajo na preusmeritev.

Negativna povezava med ekološko pridelavo in deležem samozaposlenih kmetov ni presenetljiva, saj ta podatek nakazuje na omejene možnosti kmetijskih zaposlitev, s tem pa večji pritisk na intenziviranje kmetijske pridelave v obravnavanem območju. Podobno bi lahko sklepali tudi iz negativne povezave med deležem zemljišč v ekološki pridelavi ter deležem depopulacije, večjo stopnjo brezposelnosti in posledično s staranjem prebivalstva. Podobno kot ostale študije smo potrdili pozitivno povezavo med deležem zemljišč v ekološki pridelavi in deležem višje izobraženega prebivalstva, ki odraža večje povpraševanje po ekološko pridelani hrani. Korelacijske analize kažejo pozitivno in statistično značilno povezavo med ekološko pridelavo na zavarovanih območjih (Natura 2000 in vodovarstvena območja) ter drugih območjih, ki ne omogočajo intenziviranja pridelave (območja z omejenimi možnostmi za kmetijsko dejavnost), vendar teh povezav regresijski model ne potrjuje.

\section{Diskusija}

V literaturi najdemo številne raziskave $\mathrm{v}$ podporo nosilcem odločanja, katerih namen je bil pridobiti celovitejši vpogled $\mathrm{v}$ odločanje kmetijskih gospodarstev o preusmeritvi iz konvencionalnega v ekološko kmetijstvo (Midmore s sodelavci 2001; Padel 2001; Pietola in Oude Lansink 2001; Koesling, Flaten in Lien 2008; Läpple 2010). Omogočile so kvantitativen vpogled v dejavnike preusmeritve, manj pa so se posvečale prostorskim vidikom. Nadalje so bile izvedene tudi študije, ki razkrivajo učinke prostorskih prelitij iz sosedstva, ki izhajajo iz prostorske povezanosti pridelovalcev (Frederiksen in Langer 2004; Bichler s sodelavci 2005; Lewis, Barham in Robinson 2011; Schmidtner s sodelavci 2012; Bjørkhaug in Blekesaune 2013; Wollni in Andersson 2014; Boncinelli s sodelavci 2015; Läppe in Kelley 2015). Pričujoča študija se uvršča v to skupino in dokazuje, da so učinki prostorskih prelitij prisotni pri procesih preusmeritve v ekološko pridelavo tudi na kmetijskih gospodarstvih v Sloveniji. Rezultate prostorske ekonometrične analize prostorska prelitja deloma pojasnjujemo s podobnimi naravnogeografskimi danostmi, ki prispevajo, da se pridelovalci v neki regiji podobno odločajo (na primer na območjih, ki ne omogočajo intenziviranja pridelave). Na odločanje o usmeritvi v ekološko pridelavo, sodeč po naših rezultatih, vpliva tudi komunikacija med pridelovalci, prenos izkušenj, pričakovanj, znanj in tehnologij. S tem pozitivni učinki ekološkega kmetijstva, razpoložljiva tehnična, trženjska in organizacijska znanja v neki regiji pozitivno vplivajo na povečevanje ekološkega kmetijstva v sosedstvu (Padel 2001; Schmidtner s sodelavci 2012; Bjørkhaug in Blekesaune 2013).

Rezultati naše študije se torej skladajo z rezultati sorodnih študij, ki ugotavljajo, da razširjenost ekološkega kmetovanja v Sloveniji ni naključno razporejena po prostoru. Pozitiven in statistično značilen prostorski koeficient regresijskega modela potrjuje obstoj učinkov prostorskih prelitij iz sosedstva, kar kaže na to, da se možnost preusmeritve v ekološko kmetijstvo povečuje, če je v sosedstvu ekološko kmetijstvo že v osnovi bolj zastopano. Nadalje se v ekološko kmetijstvo pogosteje vključujejo kmetije z manjšo intenzivnostjo pridelave in katerih preusmeritev v ekološko pridelavo ne terja velikih tehnoloških prilagoditev. V tem elementu rezultati sovpadajo z rezultati sorodnih raziskav, opravljenih v različnih evropskih državah - od Norveške (Bjørkhaug in Blekesaune 2013), Nemčije (Schmidtner s sodelavci 2012) in Irske (Läppe in Kelley 2015); ter tudi v Sloveniji (Travnikar in Juvančič 2013; Slabe 2015). Podobno bi pričakovali pozitivno povezanost med ekološko pridelavo ter deležem zavarovanih območij in drugih območij, ki ne omogočajo intenziviranja pridelave (območja Natura 2000 in območja z omejenimi možnostmi za kmetijsko dejavnost), vendar regresijski model kljub predhodno ugotovljenim pozitivnim korelacijam teh povezav ni potrdil. Rezultati v tem primeru odstopajo od ugotovitev Bichlerja s sodelavci (2005) ter Schmidtnerja s sodelavci (2012), da visok delež zavarovanih območij, območja 
z omejenimi možnostmi za kmetijsko dejavnost ter slabša kakovost tal pozitivno vplivajo na večjo pokritost občin z ekološkim kmetovanjem. Razlago v primeru Slovenije lahko iščemo v dejstvu, da se ekološko kmetovanje v večjem obsegu pojavlja tudi izven teh območij. Rezultati kažejo tudi, da je preusmeritev mnogokrat povezana $\mathrm{z}$ namenom povečanja prihodkov, kjer se $\mathrm{z}$ večanjem plačil za izvajanje ekološkega kmetovanja povečuje tudi pripravljenost za preusmeritev. Velik pomen ekonomskih koristi, povezanih z javnofinančnimi podporami ekološkega kmetovanja pri preusmeritvi, ugotavljajo tudi v drugih študijah (Fairweather 1999; Bichler s sodelavci 2005; Koesling, Flaten in Lien 2008; Bartolj s sodelavci 2015; Boncinelli s sodelavci 2015).

Poleg identifikacije učinkov prostorskih prelitij, je bil namen raziskave osvetliti in bolje spoznati dejavnike, ki vplivajo na odločitve slovenskih pridelovalcev pri preusmeritvi v ekološko kmetovanje. Menimo, da so dobljeni rezultati še posebej zanimivi za oblikovalce politik, saj nakazujejo nove poti, kako povečati delež kmetijskih praks, povezanih z ekološkim kmetovanjem. $V$ javnem diskurzu prevladuje prepričanje, da so javnofinančne podpore pridelovalcem najpomembnejši vzvod za dosego želenih ciljev na področju ekološkega kmetijstva, vendar raziskave kažejo, da temu ni tako. Javnofinančne spodbude so pomembne zgolj v primerih kratkoročnih preusmeritev, saj študije kažejo, da bi se pridelovalci ob manj ugodnih ekonomskih rezultatih in ob prekinitvi finančnih spodbud odločili za opustitev ekološkega kmetovanja (Koesling, Flaten in Lien 2008). Na drugi strani avtorji poudarjajo, da je za dolgoročnejše ohranjanje trajnostnega načina kmetovanja ključen dejavnik povezovanje pridelovalcev ter vzpostavitev konkurenčnih verig vrednosti iz produktov ekološke pridelave. Pozitivno k razširjenosti ekološkega kmetijstva vplivajo tudi percepcija okoljskih in zdravstvenih koriti ekološkega kmetijstva, tako v pridelovalcih samih, kot tudi družbe v celoti, ki s svojimi pričakovanji in interesi oblikujejo identiteto posameznih pridelovalcev. Predvsem Wollni in Andersson (2014) ter Läppe in Kelley (2015) ugotavljajo, da imajo družbene norme močan vpliv na razširjenost ekološke pridelave na kmetijskih gospodarstvih. V kolikor se pričakovanja družbe glede odnosa do okolja, hrane, živali in podobnega spremenijo, potem se $\mathrm{v}$ skladu s temi pričakovanji postopoma začnejo spreminjati tudi ravnanja in odločitve pridelovalcev. To kaže, da bi lahko bili javnofinančni mehanizmi učinkovitejši, če bi delovali na oblikovanje družbenih preferenc do posameznih oblik kmetovanja. Na primer s povečanim ozaveščanjem o pozitivnih učinkih trajnostnega upravljanja z naravnimi viri, bi lahko vplivali na oblikovanje preferenc potrošnikov, posledično pa bi to vplivalo na odločitve pridelovalcev, ki delujejo in se prilagajajo v skladu s pričakovanji pripadajoče socialne skupine. $\mathrm{V}$ tem vidimo tudi možnosti dodatnega preučevanja dejavnikov preusmeritve slovenskih pridelovalcev v prihodnje. Pri tem poudarjamo, da vključitev dodatnih dejavnikov lahko razkrije nekatere slabosti metode. $\mathrm{V}$ mislih imamo predvsem dostopnost podatkov. Metoda je namreč učinkovita le na dovolj majhnih prostorskih enotah (na primer občine ali kmetije), pri čemer se $\mathrm{z}$ zmanjševanjem prostorske enote zmanjšuje tudi dostopnost podatkov. Težava večjih prostorskih enot (na primer slovenske statistične regije) s sicer večjim številom podatkov pa je v tem, da se zmanjšujejo možnosti po identifikaciji učinkov prostorskega prelivanja in s tem smiselnost uporabe prostorske ekonometrije. Poleg tega gre za prostorsko agregirane podatke, kjer je zaželeno imeti večje število podatkov; v našem primeru veliko število kmetij na občino, saj bi v nasprotnem primeru agregacija podatkov (združitev kmetij na raven občine) lahko privedla do zavajajočih rezultatov. Veliko prednost metode prostorske regresije pa vidimo $\mathrm{v}$ tem, da je primerna za vrednotenje različnih strukturnih in razvojnih programov (tudi politike razvoja podeželja; Travnikar 2017). Poleg tega je rezultate prostorske ekonometrije mogoče kombinirati z različnimi drugimi metodami, ki preučujejo analize učinkov.

V kolikor priporočila oblikovalcem politik zaključimo s prostorsko povezanostjo pridelovalcev pri izvajanju ekološkega kmetijstva, ki je bila ugotovljena v vseh obravnavanih študijah, lahko rečemo, da bi bili javnofinančni mehanizmi bolj učinkoviti tudi v primeru, če bi bili usmerjeni na skupino pridelovalcev in ne toliko na posameznega pridelovalca. V pomoč bi lahko bili rezultati LISA karte vzorcev, ki razkrivajo območja kjer se pridelovalci podobno odločajo. Rezultati kažejo na prisotnost velike prostorske povezanosti in s tem učinkov prenosa informacij iz sosedstva, s čimer ugotavljamo, da lahko na vedenjske vzorce lažje vplivamo s kolektivnim usmerjanjem večje skupine pridelovalcev. Rezultat govori v prid 
vzpostavitvi kolektivnih shem, kjer bi z usmerjevalnim (svetovalnim) delom večjega števila pridelovalcev (na primer skupinska predavanja, diskusijske skupine, delavnice), strukturnimi ukrepi (spodbujanje skupinskih naložb) ekološke proizvajalce spodbujali k večjemu proizvodnemu in tržnemu povezovanju.

\section{Sklep}

S prostorsko ekonometrijo smo potrdili zastavljeno hipotezo raziskave, da imajo odločitve pridelovalcev na nekem območju, glede preusmeritve v ekološko kmetovanje, vpliv na odločitve pridelovalcev v soseščini in obratno. Prostorski koeficient regresijskega modela je potrdil obstoj učinkov prostorskih prelitij, in sicer, če bi se delež kmetijskih zemljišč v ekološkem kmetovanju v eni občini povečal za $1 \%$, bi se delež kmetijskih zemljišč v ekološkem kmetovanju sosednjih občin povečal za $0,28 \%$. Ti rezultati so v skladu s sorodnimi študijami iz tujine, ki so preučevale prostorsko povezanost med pridelovalci (Frederiksen in Langer 2004; Bichler s sodelavci 2005; Lewis, Barham in Robinson 2011; Schmidtner s sodelavci 2012; Bjørkhaug in Blekesaune 2013; Wollni in Andersson 2014; Boncinelli s sodelavci 2015; Läppe in Kelley 2015). Rezultati prostorskega ekonometričnega modela nadalje razkrivajo (pre)veliko povezanost med dinamiko in razširjenostjo ekološke pridelave in javnofinančnimi podporami. To utemeljujemo z rezultati, ki kažejo, da se pripravljenost za preusmeritev poveča, če se poveča tudi višina plačil za ekološko kmetovanje. Na drugi stani pa v kolikor bi se povečali izhodiščni zneski neposrednih plačil v kmetijstvu, bi se pripravljenost kmetij za preusmeritev v ekološko kmetijstvo zmanjšala. Tako kot druge študije (na primer Slabe 2015), tudi naši rezultati potrjujejo, da se za ekološko kmetovanje pogosteje odločajo kmetije s prevladujočo rabo travinja, pri katerih preusmeritev v ekološko pridelavo ne bi terjala večjih tehnoloških prilagoditev.

Oba rezultata razkrivata v Sloveniji veliko odvisnost ukvarjanja z ekološkim kmetijstvom od javnofinančnih podpor. Za dolgoročno in ekonomsko vzdržno ohranjanje ekološkega kmetijstva ter zadostitev naraščajočega povpraševanja domačih kupcev po domači hrani ekološkega izvora, bi bilo $\mathrm{v}$ prihodnje potrebno več napora vložiti v povezovanje ponudbe. To še posebej velja za povezovanje proizvajalcev (pretežno živinorejske) proizvodnje na trajnem travinju. Cilj tovrstnega povezovanja bi moral biti dodajanje vrednosti v procesu predelave in trženja ter ambicioznejši vstop v najbolj razširjene maloprodajne formate široke oskrbe $\mathrm{z}$ živili. Velika večina tovrstne primarne pridelave se danes namreč še vedno prodaja kot konvencionalna (Slabe 2015).

Rezultati nudijo znanstveno utemeljeno podlago k strokovni razpravi o tem, kako oblikovati uspešnejše ukrepe za izvajanje bolj trajnostnega načina kmetovanja v prihodnje. Glede na obstoj učinkov prostorskih prelitij lahko nosilci odločanja s podporo prenosu znanja, mreženju in sodelovanju med različnimi deležniki v prehranski verigi vplivajo na povečanje izvajanja bolj trajnostnih oblik kmetovanja. Rezultati kažejo tudi, da ima izvajanje javnofinančnih podpor za izboljšanje okoljskih kazalcev v eni regiji pozitivne učinke tudi na sosednje regije. Menimo, da je ena od učinkovitejših poti ozaveščanje javnosti o oblikah kmetovanja, ki zasledujejo cilje varovanja in ohranjanja naravnih virov, dobrega počutja živali, pridelave zdrave in bolj kakovostne hrane ter trajnostnega razvoja podeželja. Na spremenjene želje potrošnikov se sčasoma začnejo odzivati in prilagajati tudi pridelovalci. Poleg tega menimo, da je svetovalno delo boljše opravljati na večji skupini pridelovalcev, saj kot kažejo rezultati, ima komunikacija med pridelovalci pomembno vlogo; kjer se pozitivni učinki ekološkega kmetijstva širijo med pridelovalci, to vpliva na povečano izvajanje ekološkega kmetijstva.

S študijo širimo vsebinski in metodološki okvir raziskovalnega dela na področju kmetijstva, pri čemer lahko uporabljene metodološke zasnove koristijo tudi raziskovalcem v okviru drugih raziskav. Metoda je bila uporabljena na primeru ekološkega kmetijstva na ravni občin, brez težav pa lahko ta pristop uporabimo tudi pri drugih raziskovalnih vprašanjih in drugih prostorskih ravneh. Za prihodnje raziskovalno delo menimo, da bi bilo raziskavo smiselno vsebinsko razširiti z dejavniki družbenih norm, interesov in pričakovanj glede načinov kmetovanja, ki jih v trenutno razvitem modelu nismo uporabili. 


\section{Viri in literatura}

Anselin, L. 1988: Spatial Econometrics: Methods and Models. Dordrecht. DOI: https://doi.org/10.1007/ 978-94-015-7799-1

Anselin, L. 1995: Local indicators of spatial association - LISA. Geographical Analysis 27-2. DOI: https://doi.org/10.1111/j.1538-4632.1995.tb00338.x

Anselin, L. 2002: Under the hood, issues in the specification and interpretation of spatial regression models. Agricultural Economics 27-3. DOI: https://doi.org/10.1111/j.1574-0862.2002.tb00120.x

Anselin, L. 2005: Interactive techniques and exploratory spatial data analysis. Geographical Information Systems: Principles, Techniques, Management and Applications. New Jersey.

Anselin, L., Bera, A. K., Florax, R. J. G. M., Yoon, M. J. 1996: Simple diagnostic tests for spatial dependence. Regional Science and Urban Economics 26-1. DOI: https://doi.org/10.1016/0166-0462(95)02111-6

Anselin, L., Smirnov, O. 1996: Efficient algorithms for constructing proper higher order spatial lag operators. Journal of Regional Science 36-1. DOI: https://doi.org/10.1111/j.1467-9787.1996.tb01101.x

Bartolj, T., Slabe Erker, R., Koman, K., Kavaš, D., Cunder, T., Bedrač, M. 2015: Izdelava sprotnega vrednotenja programa razvoja podeželja 2007-2013 v letu 2014, Vrednotenje vplivov plačil I. stebra SKP in investicijskih ukrepov na uspešnost izvajanja KOP (PRP 2007-2013). Kmetijski inštitut Slovenije. Ljubljana.

Bavec, M., Repič, P., Slabe, A., Poštrak, N., Miklavc, J. 2001: Ekološko kmetijstvo. Ljubljana.

Bichler, B., Häring, A. M., Dabbert, S., Lippert, C. 2005: Determinants of spatial distribution of organic farming in Germany. Researching Sustainable Systems: International Scientific Conference on Organic Agriculture. Adelaide. Medmrežje: http://orgprints.org/6322/ (26. 9. 2016).

Bjørkhaug, H., Blekesaune, A. 2013: Development of organic farming in Norway: a statistical analysis of neighbourhood effects. Geoforum 45. DOI: https://doi.org/10.1016/j.geoforum.2012.11.005

Boncinelli, F., Bartolini, F., Brunori, G., Casini, L. 2015: Spatial analysis of the participation in agri-environment measures for organic farming. Renewable Agriculture and Food Systems 31-4. DOI: https://doi.org/10.1017/s1742170515000307

Case, A. 1992: Neighborhood influence and technological change. Regional Science and Urban Economics 22-3. DOI: https://doi.org/10.1016/0166-0462(92)90041-x

Egri, C. 1999: Attitudes, backgrounds and information preferences of Canadian farmers: implication for organic farming advocacy and extension. Journal of Sustainable Agriculture 13-3. DOI: https://doi.org/ 10.1300/j064v13n03_05

Eurostat 2016: Podatki o površinah kmetijskih zemljišč z ekološkim kmetovanjem. Medmrežje: http://ec.europa.eu/eurostat/data/database (7. 10. 2016).

Fairweather, J. R. 1999: Understanding how farmers choose between organic and conventional production: Results from New Zealand and policy implications. Agriculture and Human Values 16-1. DOI: https://doi.org/10.1023/A:1007522819471

Florax, R. J. G. M., Voortman, R. L., Brouwer, J. 2002: Spatial dimensions of precision agriculture: a spatial econometric analysis of millet yield on Sahelian coversands. Agricultural Economics 27-3. DOI: https://doi.org/10.1111/j.1574-0862.2002.tb00129.x

Frederiksen, P., Langer, V. 2004: Localisation and concentration of organic farming in the 1990s - the Danish case. Tijdschrift voor Economische en Sociale Geografie 95-5. DOI: https://doi.org/10.1111/ j.0040-747x.2004.00338.x

Getis, A. 2010: Spatial autocorrelation. Handbook of Applied Spatial Analysis. New York. DOI: https://doi.org/10.1007/978-3-642-03647-7_14

Koesling, M., Flaten, O., Lien, G. 2008: Factors influencing the conversion to organic farming in Norway. International Journal of Agricultural Resources, Governance and Ecology 7, 1-2. DOI: https://doi.org/ 10.1504/ijarge.2008.016981 
Lampič, B., Mrak, I., Potočnik Slavič, I., Bednář, P., Žufan, P., 2010: Characteristics of organic food consumers in urban regions of Ljubljana and Ostrava. Dela 34. DOI: https://doi.org/10.4312/dela.34.2.23-38

Läppe, D., Kelley, H. 2015: Spatial dependence in the adoption of organic drystock farming in Ireland. European Review of Agricultural Economics 42-2. DOI: https://doi.org/10.1093/erae/jbu024

Läpple, D. 2010: Adoption and abandonment of organic farming: an empirical investigation of the Irish drystock sector. Journal of Agricultural Economics 61-3. DOI: https://doi.org/10.1111/j.14779552.2010.00260.x

LeSage, J. P., Pace, R. K. 2010: Spatial econometric models. Handbook of Applied Spatial Analysis. New York. DOI: https://doi.org/10.1007/978-3-642-03647-7_18

Lewis, D. J., Barham, B. L., Robinson, B. 2011: Are there spatial spillovers in the adoption of clean technology? The case of organic dairy farming. Land Economics 87-2. DOI: https://doi.org/10.3368/ le.87.2.250

Manski, C. 1993: Identification of endogenous social effects: the reflection problem. The Review of Economic Studies 60-3. DOI: https://doi.org/10.2307/2298123

Midmore, P., Padel, S., McCalman, H., Isherwood, J., Fowler, S., Lampkin, N. 2001: Attitudes towards conversion to organic production systems: a study of farmers in England. Aberystwyth. Medmrežje: http://orgprints.org/10817/1/Attitude_survey.pdf (20.4.2017).

Moran, P. A. P. 1948: The interpretation of statistical maps. Journal of the Royal Statistical Society B 10. Moussis, N. 2010: Guide to European Policies. Rixensart.

Padel, S. 2001: Conversion to organic farming: A typical example of the diffusion of an innovation? Sociologia Ruralis 41-1. DOI: https://doi.org/10.1111/1467-9523.00169

Pietola, K. S., Oude Lansink, A. 2001: Farmer response to policies promoting organic farming technologies in Finland. European Review of Agricultural Economics 28-1. DOI: https:/doi.org/10.1093/ erae/28.1.1

Podmenik, D. 2012: Trendi in perspektive ekološkega kmetijstva s poudarkom na Sloveniji in Slovenski Istri. Ljubljana.

Schmidtner, E., Lippert, C., Engler, B., Häring, A. M., Aurbacher, J., Dabbert, S. 2012: Spatial distribution of organic farming in Germany: Does neighbourhood matter? European Review of Agricultural Economics 39-4. DOI: https://doi.org/10.1093/erae/jbr047

Slabe, A. 2015: Razvojni potencial ekološkega kmetijstva v Sloveniji v povezavi z doseganjem trajnostne samooskrbe s hrano. Doktorsko delo, Filozofska fakulteta Univerze v Ljubljani. Ljubljana.

Slabe, A., Kuhar, A., Juvančič, L., Tratar-Supan, A.-L., Lampič, B., Pohar, J., Gorečan, M., Kodelja, U. 2010: Analiza stanja in potencialov za rast ponudbe ekoloških proizvodov v luči doseganja ciljev Akcijskega načrta za razvoj ekološkega kmetijstva v Sloveniji do leta 2015. Zaključno poročilo, Inštitut za trajnostni razvoj, Biotehniška fakulteta Univerze v Ljubljani. Ljubljana. Medmrežje: https://www.dlib.si/stream/ URN:NBN:SI:DOC-HSZQEAJZ/d964ccac-95c6-42b0-b3f6-3f30ae50b45b/PDF (20. 8. 2018).

Slabe, A., Lampič, B., Juvančič, L. 2011: Potenciali ekološke pridelave za trajnostno lokalno oskrbo s hrano v Sloveniji. Dela 36. DOI: https://doi.org/10.4312/dela.36.93-109

Smit, M. J., van Leeuwen, E. S., Florax, R. J. G. M., Groot, H. L. F. 2015: Rural development funding and agricultural labour productivity: a spatial analysis of the European Union at the NUTS 2 level. Ecological Indicators 59. DOI: https://doi.org/10.1016/j.ecolind.2015.05.061

Travnikar, T. 2017: Vrednotenje ukrepov politike razvoja podeželja s prostorsko ekonometrijo. Doktorsko delo, Biotehniška fakulteta Univerze v Ljubljani. Ljubljana.

Travnikar, T., Juvančič, L. 2013: Uporaba prostorske ekonometrije pri vrednotenju ukrepov politike razvoja podeželja. Orodja za podporo odločanju v kmetijstvu in razvoju podeželja. Ljubljana.

Uredba (ES) številka 1059/2003 Evropskega parlamenta in sveta z dne 26. maja 2003 o oblikovanju skupne klasifikacije statističnih teritorialnih enot (NUTS). Uradni list Evropske unije L 154/1. Medmrežje: http://eur-lex.europa.eu/legal-content/SL/TXT/PDF/?uri=CELEX:32003R1059\&from=SL (14.3.2016). 
Villano, R., Fleming, E., Moss, J. 2016: Spatial econometric analysis: Potential contribution to the economic analysis of smallholder development. Causal Inference in Econometrics. Cham. DOI: https://doi.org/ 10.1007/978-3-319-27284-9_3

Wollni, M., Andersson, C. 2014: Spatial patterns of organic agriculture adoption: evidence from Honduras. Ecological Economics 97. DOI: https://doi.org/10.1016/j.ecolecon.2013.11.010

\section{Summary: Spatial pattern of the integration of farm holdings in Slovenia into organic farming}

(translated by Luka Juvančič)

Organic agriculture in Slovenia is experiencing rapid growth, which is a trend similar to other developed economies. In the period from 2005 to 2015, the share of utilised agricultural area under organic production almost doubled, from 4.6 to 8.8 per cent. Growth of the area (and the number of farms thereof) practicing organic production may be influenced by the steady growth of demand for organic food. Moreover, growth of the organic sector in the country has much to do also with stimulative policy environment, rewarding organic producers with additional area-based payments ranging currently (2015-2020) from $600 \mathrm{EUR} / \mathrm{ha}$ for areas under organic horticulture to 155 ha for permanent grassland. The measure has proven to be particularly stimulating for producers engaged in livestock production on absolute grassland, where the conversion to organic farming requires relative modest changes in the production technology. Consequently, about 84 per cent of area under organic production is permanent grassland.

The paper investigates the factors influencing the conversion of farms into organic production in Slovenia, emphasising the spatial pattern of this phenomenon. The research adds to the recent research analysing spatial spillovers in the growth of organic sector (Frederiksen and Langer 2004; Bichler et al. 2005; Lewis, Barham and Robinson 2011; Schmidtner et al. 2012; Bjørkhaug and Blekesaune 2013; Wollni and Andersson 2014; Boncinelli et al. 2015; Läppe and Kelley 2015), which all identify spatially explicit patterns, but the factors influencing this growth appear to be case-specific.

Similarly than studies listed above, the research applies spatial econometric methods to identify spatial patterns and quantitatively assess various factors that may be influencing the growth of organic agriculture in Slovenia. In addition to checking for spatial spill-overs, we are interested in the context that characterises this growth. Some of the influencing factors may indeed result from neighbourhood effects, such as acquiring new knowledge and technologies from neighbouring peers, quality and intensity of extension work. Other factors may be less spatially explicit and refer mainly to personal considerations and preferences developed by agriculture households. Factors, such as age, education and type of farming may indicate farms' readiness for conversion to organic farming.

The method is based on the integration of spatial data and econometric models, in order to detect possible patterns of common behaviour, which may be due to spatial interconnections. The choice of administrative spatial units (in this case municipalities, LAU level 2) as basis for spatial analysis is useful in order to combine the analysis of primary statistical data with relevant secondary statistical data. The analysis included 1,976 farms with total agricultural land of 28,088 hectares, which represents the total population of farms applying for public payments for organic farms in 2009, or 94 per cent of all organic farms in the country at that time. Individual farm data was obtained from administrative sources (Agency for Agricultural Markets and Rural Development) and aggregated to the municipality level. Similarly than other studies of this type (Bichler et al. 2005; Schmidtner et al. 2012; Bjørkhaug and Blekesaune 2013; Boncinelli et al. 2015), we have formed a decision model where the dependent variable is the share of agricultural land in organic production (as a percentage of total utilised agricultural area): $y$ (share of agricultural land in organic production)

$=\beta_{0}+\beta_{1} X_{1}$ (agricultural structural data) 
$+\beta_{2} X_{2}$ (socio-economic variables)

$+\beta_{3} X_{3}$ (geographical features)

$+\beta_{4} X_{4}$ (features related to organic production)

$+\varepsilon$.

Definition of the theoretical model was followed by adding the spatial weight matrix to the database, to test for possible spatial spill-overs of the dependant variable. The preliminary analysis (LISA map of spatial patterns and Moran I statistics) confirmed the existence of spatial concentration. Results of the LM-diagnostic suggest that the spatial lag model performs better than its non-spatial counterpart. The spatial lag coefficient $(\rho)$ reveals that a 1 per cent increase in the share of agricultural land in organic farming in one municipality results in a spatial spill-over in in neighbouring municipalities by 0.28 per cent. In addition, the model reveals some other factors that statistically significantly influence the conversion into organic farming. Two of them relate to the intensity of agricultural production. The coverage of municipalities with organic farming is increasing where farms are engaged in less intensive agricultural practices (i.e., grassland-based livestock production), while the conversion to organic farming appears to be faster in municipalities where farms are smaller in terms of their economic size. The model does not confirm causal linkages between organic farming and areas of special environmental importance (Natura 2000 and less-favored areas for agricultural activity). On the other hand, increased agricultural income support (i.e., CAP Pillar I direct payments) decrease the interest of farms to convert towards organic farming. The results thus suggest that production intensity and policy considerations play the prominent roles in the farms decision-making about their transition to organic production. Organic farming is a popular alternative for smaller farms with a lower intensity of production, lower budgetary income support, whose conversion to organic production does not require major technological adjustments. With regard to the economic viability of this spatial (and sectoral) pattern of organic production, improvements would be needed particularly in improved economic performance of the sector. This would require decreasing dependence from public payments, linking supply horizontally and vertically, resulting in competitive organic value chains. 